\title{
Bricolage versus breakthrough: distributed and embedded agency in technology entrepreneurship
}

\author{
Raghu Garud ${ }^{\mathrm{a}, *}$, Peter Karnøe $\mathrm{b}^{\mathrm{b}, 1}$ \\ ${ }^{a}$ Department of Management, Leonard N. Stern School of Business, New York University, Tisch, 40 W 4 St, 7-13, 10012 New York, NY, USA \\ ${ }^{\mathrm{b}}$ Copenhagen Business School, Department of Organization and Industrial Sociology, 3 Solbjerg Plads, DK-2000, Denmark
}

\begin{abstract}
We develop a perspective on technology entrepreneurship as involving agency that is distributed across different kinds of actors. Each actor becomes involved with a technology, and, in the process, generates inputs that result in the transformation of an emerging technological path. The steady accumulation of inputs to a technological path generates a momentum that enables and constrains the activities of distributed actors. In other words, agency is not only distributed, but it is embedded as well. We explicate this perspective through a comparative study of processes underlying the emergence of wind turbines in Denmark and in United States. Through our comparative study, we flesh out "bricolage" and "breakthrough" as contrasting approaches to the engagement of actors in shaping technological paths.
\end{abstract}

(c) 2002 Elsevier Science B.V. All rights reserved.

Keywords: Bricolage; Breakthrough; Technology entrepreneurship; Networks; Learning; Knowledge

\section{Introduction}

Entrepreneurship involves the discovery, creation and exploitation of opportunities (Venkataraman, 1997; Shane and Venkataraman, 2000). Traditional entrepreneurship literature primarily attributes the success and failure of such initiatives to specific individuals (see Gartner, 1988 for an extensive review). Some researchers have conceptualized entrepreneurs as possessing certain traits that set them apart from others. Others have conceptualized entrepreneurs as heroic individuals who are able to prevail by overcoming insurmountable odds. In either case,

\footnotetext{
* Corresponding author. Tel.: +1-212-998-0255; fax: +1-212-995-4235.

E-mail addresses: rgarud@stern.nyu.edu (R. Garud), pka.ioa@cbs.dk (P. Karnøe).

${ }^{1}$ Tel.: +45-38-152808; fax: +45-38-152828.
}

entrepreneurial agency is located in a few individuals who have the full-blown ability to discover, create and exploit opportunities that lie beyond the reach of most.

Departing from a conceptualization that vests agency with specific individuals, we suggest that technology entrepreneurship is a larger process that builds upon the efforts of many (Karnøe, 1991; Van de Ven, 1993; Van de Ven et al., 1999; Mezias and Kuperman, 2000; Garud and Karnøe, 2001). Skills and resources required to take an idea from its inception to commercial use have to be mobilized by drawing upon the generative impulses of actors from multiple domains (Karnøe, 1996). In other words, entrepreneurial agency is distributed across actors (Garud and Kotha, 1994; Tsoukas, 1996; Girard and Stark, 2001).

As Hayek (1945, p. 519) pointed out, each distributed actor possesses "dispersed bits of incomplete and frequently contradictory knowledge." In this 


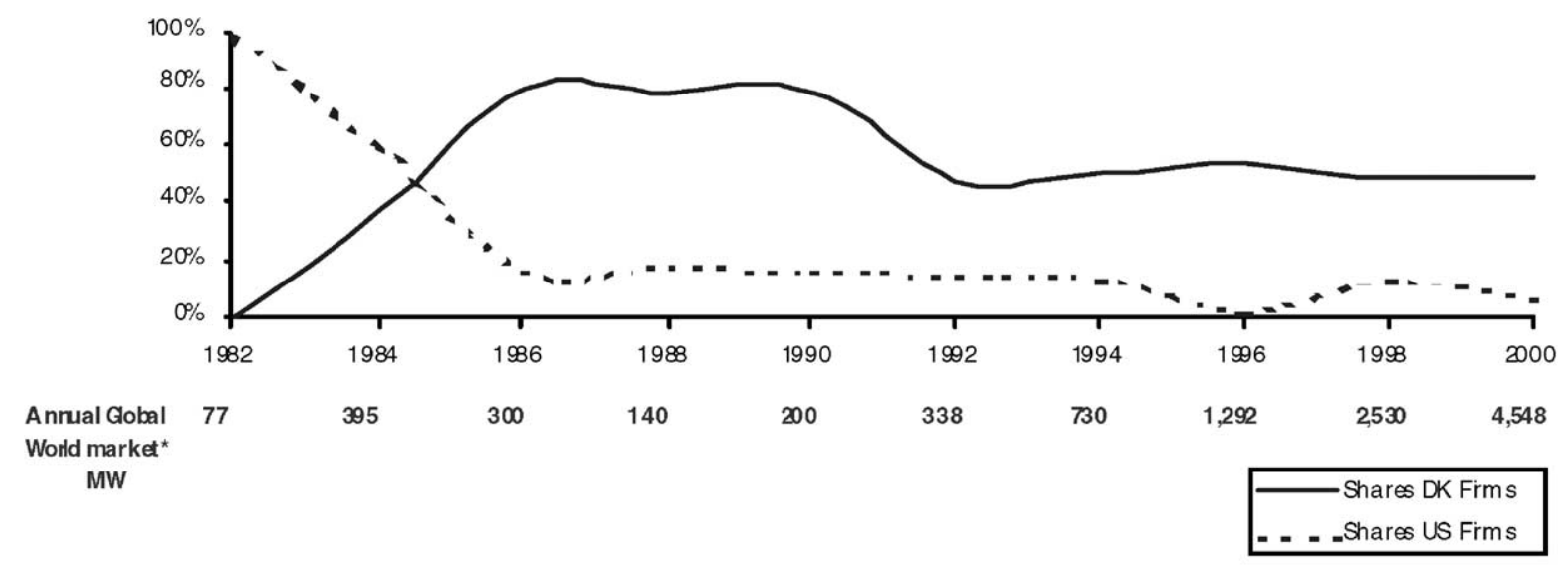

Sources: Karnøe, 1991; Cal ifornia Energy Com mission, Performance Reporting System; BTM-Consult 1994, 1997, 2001

Fig. 1. Global market shares for Danish and US firms, 1982-2000.

regard, Hayek asked how it might be possible to "extend the span of our utilization of resources beyond the span of the control of any one mind?" (Hayek, 1945, p. 527). In this paper, we suggest that the accumulation of inputs from multiple actors generates a momentum (Hughes, 1983; Molina, 1999) that can harness the inputs of distributed actors. As it gains momentum, the emerging path ${ }^{2}$ begins enabling and constraining the activities of involved actors (Garud and Jain, 1996; Kemp et al., 1988; Dosi, 1982). Actors become embedded in paths that they try to shape in real time (Garud and Karnøe, 2001; Kreiner and Tryggestad, 2002). In turn, these paths begin shaping actors over time.

As is apparent from our introduction, our perspective on technology entrepreneurship adopts a socialized view of actors, a view that is often missing in the traditional entrepreneurship literature. Moreover, implicit in our description is an appreciation that technology entrepreneurship is not just about the discovery of pre-existing options by alert individuals or speculation on the future (Knight, 1971; Mises, 1978; Kirzner, 1997; Casson, 1995; Harper, 1996; Shane, 2000). Additionally, it involves the creation of new options through the recombination and transforma-

\footnotetext{
${ }^{2}$ We use the term "paths" rather than "regimes" (Nelson and Winter, 1982; Kemp et al., 1988), or trajectories (Dosi, 1982). Paths, to us, connote a sense of "embedded agency" that we suggest actors enjoy in their involvement with a technology.
}

tion of existing resources (Schumpeter, 1942; Usher, 1954; Venkataraman, 1997; Garud et al., 1998).

These processes can unfold in several directions depending upon initial conditions and subsequent dynamics (Dosi, 1982; Nelson and Winter, 1982; David, 1985; Arthur, 1988). Eventually, one path may come to prevail over the others (Utterback and Abernathy, 1975; Tushman and Anderson, 1986; Pinch and Bijker, 1987; Arthur, 1989). Such was the case with wind turbine technology. Despite deploying significant intellectual and financial resources, actors in the US were unable to create a viable technological path (Davidson, 1996b). In contrast, actors in Denmark pursued a process that deployed modest resources to progressively build up a viable wind turbine path. Indeed, Danish firms are currently world leaders in the market for wind power (for a comparison of market shares, see Fig. 1). The market leader, Vestas, is a Danish firm with $18 \%$ of the market and four of the six largest wind turbine firms in the world are Danish (BTM Consult, 2001).

How is it possible for one group of actors deploying modest resources to prevail over another deploying far superior resources? In addressing this question, our comparative study offers two contrasting approaches to technology entrepreneurship. Actors in Denmark adopted an approach that we label as bricolage. Following Levi-Strauss (1967), we use the term bricolage to connote resourcefulness and improvisation on the part of involved actors (see also Miner et al., 2001). Bricolage was characterized by co-shaping of the 
emerging technological path as actors in Denmark sought modest yet steady gains. In contrast, actors in the US pursued a path that we label as breakthrough. We use the term breakthrough to evoke an image of actors attempting to generate dramatic outcomes. Rather than adaptiveness, an unyielding vision to leap-frog the Danish initiative characterized the involvement of actors in the US. Contrasting these approaches, Stoddard, a US wind turbine pioneer, stated:

We trusted our engineering tools too much, and felt that they could solve the hard problems, and we simply didn't believe that the engineering problems were as hard as they were. We felt bright and able ... to solve anything. We thought in a typical American fashion that there would be inevitable breakthroughs that would make the "pedestrian" Danish approach obsolete overnight. (Stoddard, 1993)

\section{Technology entrepreneurship}

Our perspective on technology entrepreneurship builds upon a body of knowledge that explicitly addresses the role of human agency in shaping new technologies. Widely referred to as the social construction of technological systems (SCOT), this literature offers detailed accounts of the micro-processes associated with technology emergence (Bijker et al., 1987). These accounts suggest that human agency is distributed across actors who are embedded in emerging technological paths.

\subsection{Distributed agency}

A pervasive theme that runs through the SCOT literature is that the emergence of a technological path cannot be attributed to any one individual actor (Bijker et al., 1987; Bijker and Law, 1992; Latour, 1991). The development of every technology involves the efforts of a multiplicity of actors (Braun and Macdonald, 1982; Garud and Van de Ven, 1987; Karnøe, 1993; Aldrich, 1999) (Fig. 2). These actors include not just those who create and discover new ideas, but also those who develop complementary assets (Teece, 1987), those in institutional forums (Garud and Rappa, 1994), and customers who offer critical inputs that shape emerging paths (Rosenberg, 1982; Von Hippel, 1986; Kline and Pinch, 1996; Tripsas, 2001).

All these actors become involved in different ways to shape an emerging technology. We use the term "involved" to connote actors' active participation from a particular "frame of reference" (Bijker, 1987; Weick, 1979). For instance, designers and producers (producers in the rest of the document) become involved based on their beliefs and experiences on the

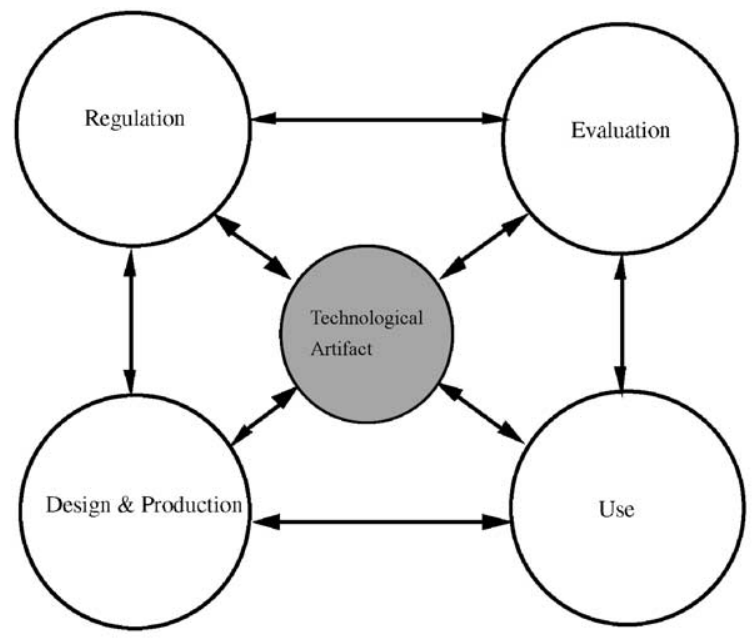

Notes: The arrows represent embedding processes. The specific em bedding processes may differ by paths.

Fig. 2. Distributed agents involved in the emergence of a technological path. 
design and production of technological artifacts. Users become involved based on the meanings that they attach to products with respect to their forms, functions and values in use (Pinch and Bijker, 1987). Evaluators become involved based on their understanding of the tests and standards required to compare and contrast different products (Constant, 1980; Garud and Rappa, 1994). Regulators enact laws based on their beliefs on the efficacy of specific policy instruments to shape the rate and direction of a technology's development (Baumol, 1990; Dobbin, 1994; Jørgensen and Karnøe, 1995).

The constitution of actors involved with any technology is not necessarily stable. Some actors may leave even as others become involved with a technological path (Latour, 1991). Moreover, even those involved at any point in time may have varying "levels of inclusion" with the technology (Bijker, 1987). For instance, in the emergence of cochlear implants, actors making advances in basic science were associated long before those who were involved in its commercial development and in developing a regulatory framework (Van de Ven and Garud, 1993). Similarly, Karnøe and Garud (2001) document how lead users offered critical inputs that shaped the emergence of the wind turbine path in Denmark well before the larger majority of users embraced them.

The presence of multiple actors with different levels of involvement implies that agency is distributed across actors. Actors become involved with a technology in different ways with different interpretive frames. No amount of additional data can reduce the "interpretive asymmetry" that exists between actors (Van Looy et al., 2001; Garud and Rappa, 1994). Indeed, technological change occurs through a synthesis of the inputs of a number of actors (Usher, 1954; Latour, 1991). From this perspective, it is not just the discovery of new opportunities by alert individuals (Kirzner, 1997) or speculation on the future (Knight, 1971). In addition, technology entrepreneurship involves the creation of new opportunities by a collective.

Observations on human agency being distributed are not particularly new (Hayek, 1945; Garud and Kotha, 1994; Tsoukas, 1996; Girard and Stark, 2001). Hayek (1945), for instance, pointed out why centrally planned economies may not be able to harness the motivations and local knowledge of the "man on the spot." For Hayek, a key question was: What governs the functioning of distributed actors?

In this regard, Hayek suggested "price" as a key mechanism that operates within an overall market process. However, price, by itself, is not sufficient to harness the inputs of distributed actors involved in the development of new technologies. After all, market processes come into play once user preferences have congealed, institutional structures have emerged, and capabilities for production have stabilized (Garud and Rappa, 1994; Dowd and Dobbin, 1997; Callon, 1998; Porac et al., 2001; Karnøe, 2001). Indeed, as preferences, institutional structures and capabilities co-evolve, there is every possibility of fragmentation as actors diverge rather than converge because of interpretive asymmetry (Garud et al., 2002). Thus, for large parts of the technology entrepreneurial process, there is ambiguity as to the specifics that may unfold.

\subsection{Embedded involvement}

We suggest that the momentum a technology generates as it accumulates inputs from actors shapes the activities of distributed actors. These inputs are generated through learning and knowledge accumulation processes that are activated as actors become involved with an emerging path (Garud, 1997). From the supply side, producers learn by doing and by experimenting (Arrow, 1962; Layton, 1971; Dutton and Thomas, 1985; Argote and Epple, 1990). Through these processes, these actors generate capabilities that are critical for the systematic design, production and distribution of goods and services. Users generate feedback when they use products and services that emerge from the technology (Rosenberg, 1982; Von Hippel, 1986; Karnøe, 1993; Kline and Pinch, 1996; Tripsas, 2001). Such learning by using generates knowledge of customers' emerging preferences. Institutional players generate other kinds of learning. For instance, those in regulatory bodies develop institutional mechanisms and policies to "steer" the technology development process (Kemp et al., 1988). More proximally, test centers generate inputs by a process of learning by testing (Garud and Rappa, 1994). The testing criteria that they codify and the results of comparative tests become valuable community level knowledge.

Thus, there are multiple opportunities for learning from the inputs of distributed actors. A technolog- 
ical "path" emerges from the intersection of these learning processes as actors' inputs result in a steady accumulation of artifacts, tools, practices, rules and knowledge (Latour, 1991). We use the term 'path' to suggest that the accumulation of inputs at any point in the development of a technology is as much a position that actors have reached as it is one that they may depart from. Indeed, actors' generative impulses are shaped by the very inputs that they offered. As Kemp et al. (1988, pp. 181-182) pointed out, “... activities are embedded in larger technological regimes, which consist not only of a set of opportunities but also of a structure of constrains in the form of established practice, supplier-user relationships and consumption patterns." In other words, actors exercise embedded agency (Callon, 1991; Garud and Karnøe, 2001).

To summarize, actors become interwoven into emerging technological paths that they shape in real time. In turn, the accumulating artifacts, tools, practices, rules and knowledge begin shaping actors over time (Giddens, 1979). In being entrepreneurial, actors cannot do anything they please. As embedded actors, they can entertain certain possibilities and not others. If they deviate too much from existing approaches, they may trigger counter-reactions that could thwart their efforts. On the other hand, if they do not deviate enough, they may not be able to galvanize a collective and generate momentum for their initiative. Entrepreneurship, from this perspective, is a process of mindful deviation (Choi, 1993; Garud and Karnøe, 2001).

The social construction of technological systems literature entertains the possibility that alternative technological paths may unfold (Dosi, 1982; Bijker et al., 1987). For instance, there were two main paths in the emergence of cochlear implants (Garud and Rappa, 1994). Each progressed along certain directions based on starting assumptions of the actors involved and the learning processes that unfolded. Differences between paths were manifest in the kinds of designs (single or multi-channel), evaluation routines (environmental sound detection or open speech recognition), users' profiles (drawn from a broad spectrum or from a motivated group) and regulatory requirements (the device specific criteria that emerged to evaluate safety and efficacy of cochlear implants by the US Food and Drug Administration). These path specific attributes, in turn, shaped the engagement of the actors involved.
The existence of multiple technological paths implies that micro-learning processes and therefore the inputs of actors involved can differ by paths. In other words, the nature of embedding of the actors involved can vary by technological paths. Consequently, to understand the specific nature of embedding requires an appreciation of the dynamics that unfold within and across alternative technological paths.

\subsection{Summary}

Technology entrepreneurship, in summary, has several interrelated facets. First, it is not just about discovery or speculation, but involves creation as well. Such creation occurs as different types of actors become involved with an emerging technological path. The multiplicity of actors involved with different frames suggests that this is a distributed process with interpretive asymmetries generating opportunities through a process of creative synthesis. Second, these actors are embedded in the very inputs that they have generated through their involvement with a technological path. Actors become embedded in these knowledge structures that then act as platforms for their departure. Thus, agency associated with technological entrepreneurship is not only distributed, but is embedded as well. Third, the specific embedding processes may vary for different technological paths, each prescribing a particular developmental logic depending upon starting assumptions and subsequent learning processes that unfold. In sum, agency associated with technology entrepreneurship is distributed, embedded and can vary by paths.

We explicate our perspective with accounts of the emergence of wind turbine paths in Denmark and in the US. Of interest here are contrasting approaches that actors in Denmark and in the US pursued. Actors in Denmark pursued a low-tech approach that they steadily improved. Those in the US pursued a sophisticated high-tech approach. Exploring how and why actors in Denmark prevailed over those in the US can shed light on micro-processes that have the potential to overcome advantages conferred by a sophisticated high-tech approach backed by large-scale resources. As Pinch (2001, p. 397) pointed out:

by problemetizing the notion of a dominant path and examining what the alternatives were, we are able to draw attention to the underlying dynamics 
even of dominant stable paths of technological development.

\section{Distributed agency}

Wind turbines comprise many interactive parts that work together to convert kinetic wind energy to electromagnetic energy. The design of wind turbines requires knowledge of electronics, mechanics, hydraulics, advanced materials and aerodynamics. Modern wind turbines are not based on any new dramatic inventions or recent scientific discoveries (Golding, 1955; Shepard, 1990). Rather, modern wind turbines embody the steady accretion of inputs from many actors. This is true of the emergence of the wind turbine paths in Denmark and in the US.

\subsection{Wind turbine path in Denmark}

One can trace the origins of the modern wind turbine to a design developed by Juul in the 1950s. During the energy crisis of the early 1970s, it was Riisager, a carpenter, who first recontextualized Juul's design with materials such as wood and lorry gears available to him. Many others were involved including Jorgensen, a skilled mechanic, who improved upon Riisagers's efforts to design an active yaw for wind turbines. Jorgensen was among the first to use fiber-glass blades produced by an engineering student, Nielsen. Vestas Wind Systems, currently the world's largest wind turbine manufacturer, licensed the right to use Jorgensen's design in 1979.

By 1980, besides Vestas, there were nine other Danish wind turbine firms, with the top three holding 63\% of the Danish market (Karnøe, 1991). Instead of pursuing a design intensive R\&D approach, these firms deployed prototypes designed with simple engineering heuristics to engender a process of trial-and-error learning. Firms also learnt from each other at Windmeetings that began in 1976. These meetings culminated in the formation of the Windmill Manufacturers Association in 1978. These firms are leaders in the fast-growing world market for wind power with a market share of around $45-51 \%$ in 2001 (BTM Consult, 2001).

The emergence of wind turbines involved not just the discovery of pre-existing underutilized resources by specific individuals, but also, a transformation of resources by many different actors. Owner-users played a key role. Concerned about their investments in wind turbines, early owner-users mobilized to form the Danish Wind Mill Owners' Association in 1978 to seek design features that would enhance the safety and reliability of wind turbines (Tranæs, 2000). Based on the association's inputs, manufacturers incorporated a double brake system that is still in use. Even for a seemingly straightforward technology such as wind turbines, one can see how dimensions of merit emerged through a synthesis of the inputs of several actors.

Engineers at the Danish Wind Turbine Test Station (DWTS) were another group of actors to play an important role. The DWTS was established in 1978 to service the emerging wind turbine industry (Risø, 1988). The test station comprised of four engineers with diverse competencies and skills ranging from aerodynamics, testing, measurement, and engine mechanics. The mix of competencies at the DWTS made it possible for the engineers to understand the complexities of wind turbine operations and to participate meaningfully in the development of the industry.

Soon after the DWTS came into being, the Danish government passed a law that required wind turbines to be certified before owner-users could gain subsidies from the Danish government. These government regulators were yet another group of actors. They had become involved with the emerging path by earmarking R\&D money for wind power in response to the energy crisis of the early 1970s. By enacting policies that offered market subsidies, these regulatory actors played important roles in "steering" the emerging path to construct "transition paths" (Kemp et al., 1988, 2001).

The law requiring certification led to increased interactions between engineers at production sites and those at the DWTS. Recognizing that knowledge was embedded in those who were designing and deploying the first wind turbines, DWTS engineers began learning from those in industry and began positioning the test station as a knowledge resource for industry participants (Ris $\varnothing$, 1988). In collaboration with the industry, the test center began establishing testing criteria for gaining governmental subsidies.

This brief description highlights a few facets of human agency in the development of the Danish wind turbine path. Many actors were involved including 
producers, users, evaluators and regulators. Each shaped the emerging path from a particular vantage point. These actors became involved at different points in time with certain events triggering greater involvement. For instance, the energy crisis of 1974 triggered the involvement of actors in the policy regimes. Potential investment losses triggered users' involvement. A need to accumulate emerging knowledge and then the need for certification triggered the involvement of the DWTS. All the while, designers and producers continued developing and deploying wind turbines.

A technological path emerged as each actor's inputs progressively began enabling and constraining the activities of others. Users' inputs shaped producers' designs, producers' 'low-tech' capabilities shaped approaches pursued by the test station, the test station's approval procedure shaped the minimum load paradigm for producers, regulators shaped policy such as placing a restriction on investments by private users when wind installations began to grow too fast. In this way, the inputs of these many actors co-shaped the accumulation of artifacts, tools, practices, rules and knowledge that in turn began shaping the actions and interactions of involved actors.

\subsection{The US wind turbine path}

Distributed agency apparent in the development of the Danish wind turbine path is to be found in the emergence of the US wind turbine path as well. Early efforts can be traced to a design by Jacobs in the late $1920 \mathrm{~s}$, whose small $2-5 \mathrm{~kW}$ stand-alone machines equipped with storage batteries were bought by farmers (Righter, 1996). At the other end of the spectrum were Putnam's 1.5 MW giant grid-connected wind turbines that were deployed between 1934 and 1945 (Putnam, 1948). Putnam's design shaped US's large-scale wind turbine program that gained momentum with the energy crisis of $1973 .{ }^{3}$ Facets of the approach adopted in this program, including its linear top-down orientation and the quest for a breakthrough, spilt over to the small-scale entrepreneurial US wind turbine path.

\footnotetext{
${ }^{3}$ For more details on the large scale program, see Karnøe (1993), Righter (1996), and Gipe (1995).
}

Shaping the emergence of the nascent technology path were pioneers such as Gipe and Stoddard. Gipe began refurbishing and selling Jacobs' windchargers (Righter, 1996, pp. 162-166). Around 1973, Stoddard joined the University of Massachusetts where he taught an engineering course on wind turbines from which around 30-40 engineers graduated. Stoddard (1993) decided not to pursue Juul's design rejecting it as being "too simplistic." Instead, he and his colleagues decided to pursue a design that had emerged from Batelle Laboratories, Canada. USWindPower, one of the first US firms, adopted the three-bladed light-weight moderately sophisticated wind turbine that Stoddard and his colleagues designed.

Besides USWindPower, about 20 other firms became active between 1974 and 1986. Amongst them was Fayette that designed its wind turbines with the help of external consultants, including Stoddard. In the early 1970s, the Carters from Burkburnett, TX, placed their bets on a design more advanced than the one at USWindPower. Carter Jr. had worked with the Bell Helicopters Design and Development Group. Carter Sr. had worked on extruded fiber-glass casing for Minutemen Missiles for many years. Their highly advanced turbine designs incorporated a twobladed light-weight, flexible design with a teeteringhub.

As in Denmark, a test and research center for small-scale wind turbines was established in the US. This center, originally called the Solar Energy Research Institute (SERI) and later the National Renewable Energy Laboratory (NREL), was formally a part of the solar energy research national wind power program (Divone, 1980). One of its objectives was to develop a knowledge base of fundamental engineering science. Another was to develop and apply standards to identify the "best" designs for R\&D contracts. Based on the standards established and the tests carried out by this center, over US\$ 14 million in development contracts were deployed between 1978 and 1982 (Karnøe, 1993; Nelson, 1983).

Collective action apparent in Denmark also emerged in the US. In 1974, a national trade association, the American Wind Energy Association (AWEA), was founded. The AWEA comprised a mix of actors including wind power plant developers, wind turbine manufacturers, utilities, consultants, insurers, financiers and researchers. A key purpose of this 
Table 1

Embedding processes in the Danish and US technological paths

\begin{tabular}{|c|c|c|}
\hline Actors & Denmark & US \\
\hline $\begin{array}{l}\text { Designers and } \\
\text { producers }\end{array}$ & $\begin{array}{l}\text { Design heuristics based on experience with } \\
\text { agricultural equipment; reliability of key concern } \\
\text { Collaborative network between designers, } \\
\text { producers and suppliers } \\
\text { Several scale-up steps with product development } \\
\text { efforts in-between scale-ups }\end{array}$ & $\begin{array}{l}\text { Engineering (science) based on aerospace framing; } \\
\text { aerodynamic efficiency of key concern } \\
\text { Lack of collaborative network between designers, } \\
\text { producers and suppliers } \\
\text { Fewer scale-up steps with little product } \\
\text { development effort in-between scale-ups }\end{array}$ \\
\hline Users & $\begin{array}{l}\text { Direct learning points from multiple users } \\
\text { Incentives to provide critical inputs } \\
\text { Mobilized to form an association that published } \\
\text { comparative performance of wind turbines }\end{array}$ & $\begin{array}{l}\text { Indirect learning points from limited set of users } \\
\text { Poor incentives to provide critical inputs } \\
\text { Mobilized to form an association with producers } \\
\text { to lobby government }\end{array}$ \\
\hline Evaluators & $\begin{array}{l}\text { Co-development approach } \\
\text { Comparative tests of wind turbines offered critical inputs } \\
\text { Testing standards co-evolved with the technology } \\
\text { being developed }\end{array}$ & $\begin{array}{l}\text { Selection approach } \\
\text { Lower emphasis on comparative tests } \\
\text { Testing standards based on generic engineering } \\
\text { science design knowledge that did not co-evolve }\end{array}$ \\
\hline Regulators & $\begin{array}{l}\text { Strategically steered the activities of the various actors } \\
\text { Policies engendered greater involvement of actors } \\
\text { in wind turbine path } \\
\text { "Modulated" market processes }\end{array}$ & $\begin{array}{l}\text { Created and abruptly closed huge opportunities } \\
\text { Policies did little to increase involvement of actors } \\
\text { in wind turbine path } \\
\text { "Episodic" quality to intervention }\end{array}$ \\
\hline
\end{tabular}

organization was to lobby actors in the US Congress to shape emerging wind and renewable energy legislation.

Indeed, actors in the US government, like their Danish counterparts, played active roles in shaping the emergence of wind turbine. Policy makers offered market subsidies and tax credits to users and producers whose wind turbines were certified by the SERI/NERL. In combination, these policies generated huge incentives to install wind turbines in California in the early 1980s, a period that came to be known as the "wind gold rush."

This list of the actors involved in the two countries, though brief, illustrates the distributed nature of agency. Actors from different domains became involved at different points in time. These actors were not passive observers but were actively involved in mobilizing and shaping emerging technological paths. Whether it was through inputs to the design of blades or through inputs to the rules governing approvals for market subsidies, actors in both paths progressively shaped their respective wind turbine paths. In turn, these accumulating inputs began shaping the involvement of the different actors. However, the ways that the actors became involved with their emergent paths differed across the two contexts.

\section{Differences in embedding processes}

We use overall contrasting labels "bricolage" and "breakthrough" to highlight the differences in the embedding processes associated with actor involvement in the two paths (see Table 1 for a summary of the differences). Bricolage, the label we use to describe embedding processes in the Danish path, was characterized by emergent co-shaping. For instance, designers and producers steadily scaled up designs all the while incorporating the inputs of the many actors involved. Users offered continual feedback while those in test centers developed evaluation routines that co-evolved with experiences in the field. All the while, policy makers "modulated" the emergence of the market to keep the technological path alive.

A different logic of distributed agency was apparent in the development of the US wind turbine path. Designers and producers tried to "leap-frog" the Danes with high-tech designs as developers hyped up future performance of wind turbines to reap greater profits. Researchers at the test center pursued a "linear" engineering science based technology-push model as their basis for interactions with industry participants. Regulators enacted policies to jump-start the technology, spur the formation of a huge market, and then 
abruptly removed subsidies. These efforts were consistent with an approach that sought a breakthrough.

\subsection{Design and production}

There were key differences in the ways design and production engineers became involved in the two paths. Actors in the US started with a high-tech design, took large steps in design scale-up, and did not engage in much product development in-between stages. In contrast, actors in Denmark started with a low-tech design, took smaller steps in design scale-up, and engaged in product development in-between stages. Other differences were apparent in the collaborative networks within which these turbines were being designed and produced. The Danish path was characterized by considerable interaction among those in a network in contrast to the US path where such collaborative processes were muted.

\subsubsection{Processes in Denmark}

Rosenberg (1982, p. 143) defined technology as "knowledge of techniques, method, and designs that work, and that work in certain ways and with certain consequences, even when one cannot explain exactly why." Our ability to influence and shape emergent outcomes in technological systems via knowledge embedded in practices often surpasses our ability to analyze and model them explicitly (Garud, 1997). This was the situation with early firms in Denmark.

Each firm possessed a core group of skilled workers, technicians and a few practical engineers. Such a mix was representative of the "mechanical skill" base that had emerged as a result of a "practical engineer" education typical of the Danish machine industry. These firms began developing wind turbines without an appreciation of the complexities involved. The people involved saw the wind turbine as presenting a set of problems similar to those they had confronted in the construction of agricultural machinery. Lacking explicit theoretical knowledge on turbine aerodynamics, practical engineers initiated a learning process by deploying and redesigning components that often failed but could be improved. Many a problem was solved by "throwing metal" at the problem. The heavy-weight low-speed design that emerged unintentionally reduced design risk by ensuring that internal weight overshadowed aerodynamic loads (Stoddard, 1986, p. 89).

Manufacturers initially confronted problems that had to do with structural dynamics and operational reliability. Only later did aerodynamic efficiency of blade profiles emerge as key design challenges. The two former boat manufactures that supplied the wind turbine blades did not possess specific aerodynamic knowledge. Consequently, they sought technical assistance from a Danish Technical Service Institute. Only gradually did the blade designs evolve to embody specific aerodynamic properties (Karnøe, 1991).

Other suppliers emerged to build hubs, high quality shafts, mechanical brakes, electronic control systems, components for the yaw-system, and quality gears to substitute for the original lorry gears. Design and production of many components were undertaken in a collaborative network setting that encouraged and created an interactive learning network within an emerging industrial cluster (Karnøe, 1991; Porter, 1990; Lundval, 1992). In this sense, the wind turbine industry emerged using the traditional Danish collaborative "small and medium sized enterprise" (SME) industry structure (Kristensen, 1992; Karnøe et al., 1999). As part of such a SME structure, Danish wind turbine producers were able to benefit from the competencies of firms distributed across a range of suppliers in a network.

Over time, there emerged a large amount of practical and explicit knowledge which steadily improved turbine specific competencies. This was manifest in the number of steps involved in design scale-ups (see Fig. 3). Such a scale-up approach was ideally suited for fostering on-going learning, thereby allowing firms to concentrate on solving and learning from a small number of manageable problems between steps. A momentum for learning was maintained through product development efforts in-between scaled up versions. A lower emphasis was placed on optimization of production processes as firms continued to experiment with new wind turbine features.

\subsubsection{Contrasting processes in the US}

Reflections by Stoddard, a pioneer in the US wind turbine industry, succinctly capture the differences in the approaches pursued by the US designers and producers in comparison to their Danish counterparts. 


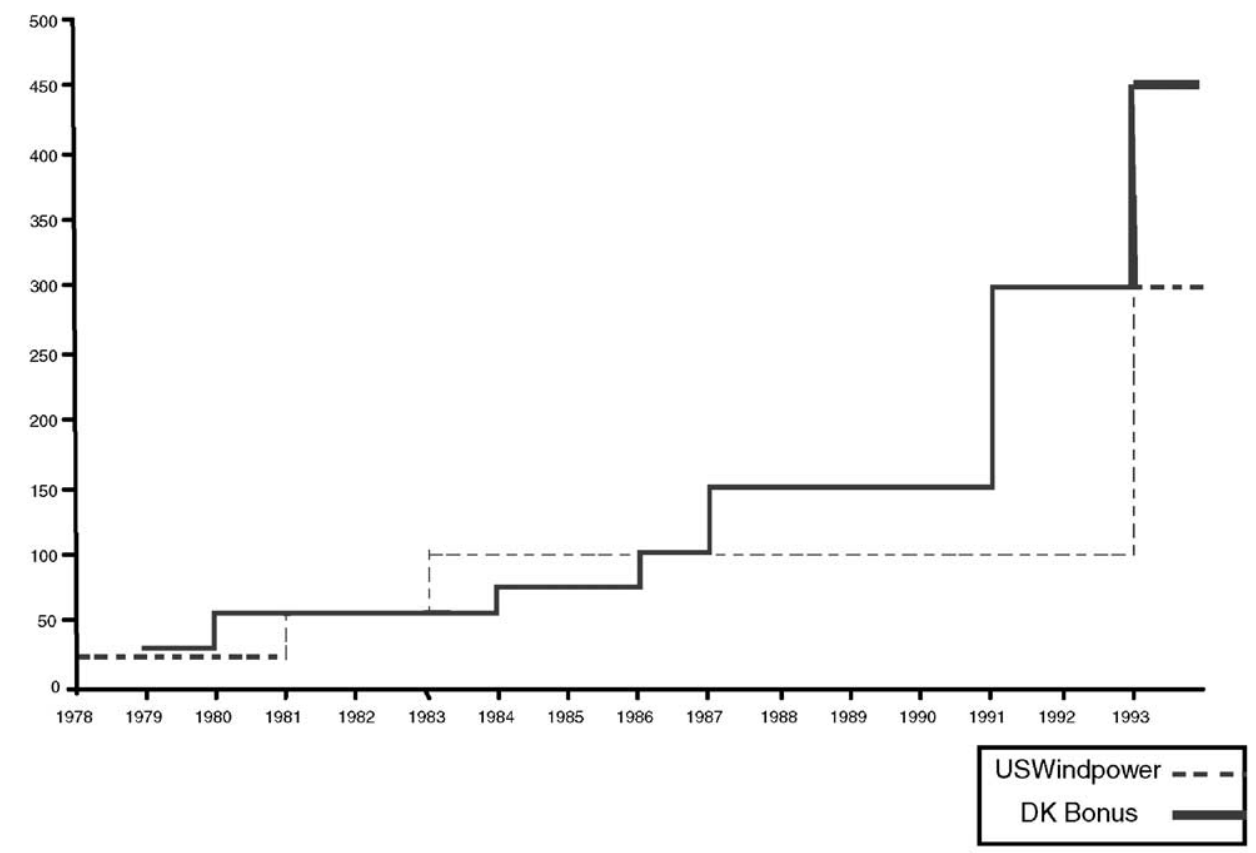

Notes: We have shown the scale-up steps for two of the major firms - Bonus in Denmark and USWindpower in the U.S. Scale-up of the remaining firms in the two countries boadly followed similar jumps. As this chart shows. Bonus went through many more steps as compared to USWindpower. Moreover, Bonus had on-going product development in between steps as compared toUSWindpower that did not.

Fig. 3. Design scale-up steps for two major firms.

I remember very distinctly in the 1970's thinking why we were not pursuing the 'Danish design' features that were already successful. I felt their approach was 'too easy' or not challenging enough. (Stoddard, 1993, p. 1)

Practitioners in the US approached design from an engineering science knowledge base, conceptualizing problems in terms of the formal, theoretical language of aerodynamics and structural dynamics. Following what is commonly labeled as a "linear" model of discovery, technical problems were to be solved by developing and applying engineering science knowledge. The goal of many engineers was to create a design that had radically changed features compared to existing technology (Stoddard, 1993). From the beginning, managers of the US Department of Energy (DOE) Wind Program and Research Center believed that sophisticated light-weight, hightech designs would "leap-frog" the simpler and sturdier Danish designs and win the competitive race (Davidson, 1993). Indeed, US engineers did not design for long-term reliability but for aerodynamic efficiency.

Most design engineers adopted an "aerospace framing" with the governmental program reinforcing this belief. This frame was inscribed in mental models and computer programs of airplane design codes focused on aerodynamic efficiency and low weight, and incorporated representations of wind loads as if they were in a steady flow (see Fig. 4; DOE, 1984; Garrad, 1988). However, wind turbines were different enough in their functioning and in their conditions of use to make much of the knowledge from the aerospace field not only inapplicable but also misleading. Such a misrepresentation directly contributed to the low reliability and poor performance of many turbines designed in the US (Stoddard, 1993, p. 2).

US wind turbine firms viewed design of turbines as their primary task with operational reliability and production quality remaining of secondary concern. Indeed, firms' design and production functions were poorly integrated with little internal communication and collaboration between the two activities. Such a 

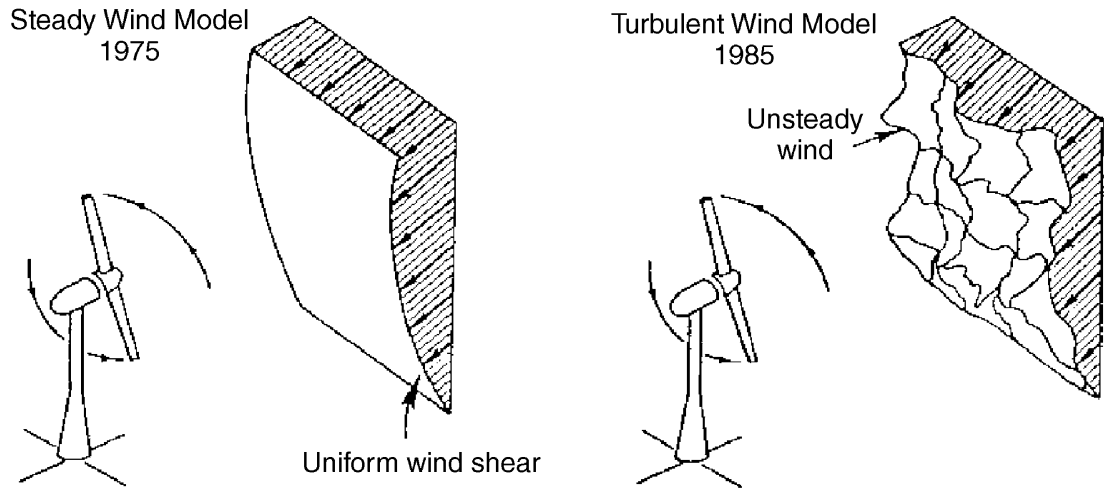

Notes: This figure is from"DOE Five Year Research Pla n on wind power, 1985-90." This figure depicts the understanding of wind flows by actors in the U.S. and cha nges that occurred over time.

Fig. 4. Changes in the representation of the wind flows by actors in the US.

de-coupling of design from production was consistent with the then prevalent mass production ethos encouraging workers with narrow skills to "do" and not to "think" about production problems (Noble, 1984).

Wind turbine design engineers became insulated from the hands-on problems encountered in turbine construction and maintenance, making it very difficult for this practical knowledge to feed back to inform the engineers' more theoretical knowledge base. In one communication, a field engineer pointed out "it was a struggle to make them (design engineers) listen to weaknesses we had encountered that might be important for (the design of) other parts of the machine" (Karnøe, 1993). In USWindPower, members of the design team for a new groundbreaking design were not allowed to talk to other engineers for fear that information would leak out to rivals.

The nature and extent of interactions between producers and suppliers was an additional area of difference in the two cultures. In the US, most relationships were one-time, short-term contracts motivated by profits at the expense of efforts to foster knowledge sharing and interactive learning (Lundval, 1992). Engineers were discouraged from talking with peers in other firms for fear of disclosing trade secrets. An engineer from one firm was even fired for breaching this norm. It is not surprising that co-shaping processes characteristic of the Danish path were muted in the US.

The desire to come up with something radically new may be a deeply ingrained American value (Hughes, 1989; Florida and Kenney, 1990). This tendency can be seen in the strategies for design scale-ups (see Fig. 3). Three firms, whose largest turbines were in the $25-100 \mathrm{~kW}$ range, all decided to ramp up by several orders of magnitude to $300 \mathrm{~kW}$ for their next generation of machines. The large number of major, novel, and complex problems that these firms encountered with such a scale-up approach made it difficult for them to engage in systematic learning. Some constellations of problems proved to be simply intractable.

Exacerbating these issues was a lack of on-going product development efforts in-between scale-ups. Managers in two of the dominant firms (USWindPower and ESI) made it clear that they did not want to invest much in on-going technology development in-between stages (Karnøe, 1993). The focus was on reducing the costs of existing designs, resulting in US Windpower's case, in the production of 4000 of their then current turbine models. Moreover, there appears to have been a lack of continuity in the composition of teams involved in the design of each new generation of turbines. For instance, a wind farm developer bought ESI in 1984 and promptly fired several design engineers while deploying others as field engineers. In USWindPower, new product development efforts came to a standstill between 1983 and 1987 .

\subsection{Owner-users}

The literature on the social construction of technological systems draws attention to the important roles that users play in shaping the form, function 
and attributes of technological artifacts (Bijker et al., 1987; Von Hippel, 1986). Indeed, it is difficult to ignore the inputs of owner-users in the development of the two paths. However, the specific nature of involvement of owner-users in the two paths differed, generating different dynamics.

\subsubsection{Processes in Denmark}

The Danish industry began by selling its early, small turbines to individual users and cooperatives. As interest in the newly emerging path grew, "do-it-yourself" owner-users began organizing "wind meetings" several times a year (Tranæs, 2000). These meetings helped create a forum for sharing knowledge and a network whose participants felt they were part of a larger community (Jørgensen and Karnøe, 1995).

By the early 1980s, a few hundred wind turbines had been installed. The presence of many dispersed installations functioning under different conditions of use created multiple learning opportunities. Geographical proximity to wind turbines offered producers an opportunity to rapidly learn about problems and to keep turbines in operation (Gipe, 1995). Learning by using that occurred with these small wind turbines formed the basis for the gradual design scale-up to the larger turbines now being deployed by utilities.

We have already alluded to the critical role that the Wind Mill Owners' Association played in obtaining a fail-safe braking system (Gipe, 1995, p. 59). Organized actions by the association were also instrumental in finalizing an agreement with power utilities to establish grid connections and in formalizing a mechanism for consumers to pay for the use of wind power. In addition, the Wind Mill Owners' Association, in 1980, began publishing monthly reliability and performance data on most turbine models. These publications created market "transparency" that forced producers to compete on market-defined evaluation criteria (Karnøe, 1991; van Est, 1999).

Experiences in the Danish domestic market generated confidence in Danish firms to venture overseas. An opportunity presented itself in the US in the early 1980s. Federal and state tax credits as well as the Public Utility Regulatory Policies Act (PURPA) guaranteed a profitable market for wind power in California. However, this sudden growth opportunity also created tremendous technological and organizational challenges. Wind patterns in California were turbulent, with high speeds and great variability, subjecting Danish turbines to greater stresses than they had encountered before. Despite superior performance over the US designs, there nevertheless arose around 1987 an unexpected need for repairs on a sizable number of Danish wind turbines.

Danish manufacturers soon began realizing the magnitude of the efforts required to service capital equipment in a distant export market under much different conditions of use. Moreover, government market subsidies began expiring just as service obligations began mounting and export sales plummeted. Unprepared to cope with these problems, the industry experienced a major crisis. Two of the largest firms declared bankruptcy. Others, despite hardships, kept key designers and technological competencies in place. This continuity made it possible for them to learn from their Californian experience. Supported by the home market, these firms continued developing and scaling-up new generations of more powerful and more efficient turbines (Karnøe, 1991).

Eventually, new global markets began emerging in response to increased environmental concerns. Indeed, global wind turbine markets have grown at a rate of $31 \%$ per year during the period 1995-2000. Danish firms could capitalize on this opportunity as they had a proven, robust technology and experience with foreign markets (see Fig. 1 for market share).

\subsubsection{Contrasting processes in the US}

In the US, producers did not perceive the dispersed market to be all that promising and decided to focus instead on the centralized "wind farm" concept that emerged in California. This pattern of use limited the number of interaction points from which US producers could learn. Moreover, wind turbine ownership structures were very different in the two countries (see also Kemp et al., 2001). Unlike in Denmark where owner-users had considerable financial exposure, those in the US were developers keen to exploit subsidies and tax credits to generate profits that were not dependent on how much power wind turbines produced. A separation of ownership from usage that the incentive structure created led to dampened and delayed feedback from those operating turbines to firms that designed and produced them (Gipe, 1995; Righter, 1996). 
This reduced feedback had a negative impact on the US wind turbine path particularly during the California boom and bust period of 1980s. New firms rushed into the industry in an attempt to cash in on wind farms' apparently limitless demand for an immature, untested technology. It appears that the speculative fever of wind farm development may have been to the detriment of the nascent wind turbine industry. As Davidson (1996a, p. 4) noted:

... generous public subsidies encouraged projects where money was made mostly in the financial wheeling and business dealing before anything was in the ground, regardless of whether the turbines actually worked.

American producers apparently learnt little from these failures. Their aerospace framing incorporating assumptions of steady-state wind flows (see Fig. 4) in combination with a belief in the supremacy of their high-tech designs rendered them "blind with respect to other technological possibilities" (Dosi, 1982, p. 153). To them, these early failures were merely start-up difficulties, the normal growing pains experienced by a new industry. Moreover, several US companies had a 2-year backlog of turbine orders (van Est, 1999). While problems were expediently "solved" by replacing failed components, the time-consuming process of analyzing problems and redesigning wind turbines was not undertaken.

Eventually, American turbines began failing in large numbers (Karnøe, 1993). Several factors created a serious backlash against wind power that resulted in long-lasting damage to the US wind turbine path. These included unrealistic expectations generated by manufacturers' hyped-up performance projections juxtaposed against the technology's subsequent poor performance. Fueling this backlash were negative images that the media portrayed of wind farms as tax scams (van Est, 1999) and publicized criminal fraud cases against "fly-by-night" developers. As Stoddard (1993) stated, "It seems ... that the only feedback we really got was from the lawyers and lawsuits."

In sum, early users offered little and poor feedback to wind turbine producers. There also was little pressure to develop independent mechanisms for information disclosure and evaluation that could have made the market more "transparent" and helped to protect users from poor technology. Neither producers nor government agencies made much effort to provide accurate, reliable and timely performance data.

\subsection{Test and research centers}

In the development of many technologies, independent test and research centers play important roles. These institutions generate community level knowledge through research as well as industry wide standards employed to evaluate and compare different product offerings. Products that conform to these standards gain significant legitimacy over others (Constant, 1980; Garud and Rappa, 1994; Aldrich and Fiol, 1994; Rao, 1998). The specific roles that these test and research centers play in serving as selection mechanisms or as forums for collective sense making can have a key impact on paths. In this regard, test centers that were established in the two countries served very different roles and had different impacts.

\subsubsection{Processes in Denmark}

The DWTS was established in 1978 at the initiative of a group of engineers with an interest in wind energy. From the beginning, activities at the center had a strong practical orientation regarding how problems were defined, prioritized, and addressed. Engineers from the turbine industry itself shaped the research agenda. The first group of engineers at the DWTS did not even include senior scientists (Andersen, 1993). Reflecting on the center's humble beginnings, an article contained in the DWTS's monthly publications pointed out:

In the 1970's, when wind turbine used old lorry rear wheel-hangers as machine parts, the "research activities" of the DWTS involved visiting "scrap-dealers" to help find the most suitable lorry rear wheel hangers. Economic resources were few, but creative initiatives were a plenty. (Translated from Ris $\varnothing, 1988$, p. 3)

In 1979, the DWTS faced a major challenge in developing an adequate model of interaction with the emerging industry. A Danish government act installed a coercive mechanism, a compulsory approval system for wind turbines modeled after a Ministry of Housing program and implemented through the DWTS. The government act established a market stimulation 
mechanism in the form of a market subsidy for $30 \%$ of the total cost of a wind turbine, payable to buyers. The approval system was included to ensure that subsidies would not be wasted on poor technological designs. The institution of this approval system implied that there was no choice for firms but to interact with the DWTS to gain approvals.

Initially, engineers at the DWTS did not possess the necessary knowledge required to create robust criteria for the evaluation of wind turbines. Indeed, it was not clear to anyone in the emerging technological path as to what the criteria should be. As Lundsager and Jensen (1982, p. 405) stated:

Rigorous criteria were unavailable and time was needed for the development of such criteria. Secondly, for the developing windmills it was considered beneficial that the licensing procedure be not too restrictive at first. (Lundsager and Jensen, 1982, p. 405)

To build up a knowledge base, DWTS engineers began interacting with early wind turbine producers and users, continually incorporating suggestions that emerged into the DWTS's research agenda (Lundsager and Jensen, 1982). From these intense interactions emerged a set of criteria. Some operationalized users' safety requirements. Others codified some of the Ministry of Housing's experience with the construction and building industry regarding structural stress and fatigue. Overall, standards were on the conservative side because of the uncertainties involved. A firm could deviate significantly from target standards, but to do so, the firm had to convince the DWTS that its wind turbine design would work. In the process, the standards themselves co-evolved (Rosenkopf and Tushman, 1993; Van de Ven and Garud, 1993; Nelson, 1994; Jain, 2001).

Along with the emergence of the DWTS, another complementary institution emerged in the form of "contact-group-meetings." The contact group comprised of diverse stakeholders of the Danish wind turbine path including producers, the Wind Mill Owners' Association, The Organization for Renewable Energy, involved ministries, Electric Utilities, and the Test Station (Ris $\varnothing, 1988$, p. 8). This initiative is reflective of a participative style that is used in Denmark when public money is involved in technology development. This contact group served as an important forum for co-shaping policies governing the emerging technological path.

In sum, the DWTS played a critical role in helping the industry develop a knowledge base as they systematically tested wind turbines of different vintages and vendors. The extensive interactions between turbine firms and DWTS personnel facilitated numerous iterations of design, construction, tests and problem-solving prior to the approval of a new turbine. These dynamics contributed immensely to the cumulative building of a research agenda within the industry (Andersen, 1993). The knowledge generated as a result of reviewing and interpreting measurement data from the DWTS ultimately became very important to turbine designers. Full-scale tests, measurements, and experiments on commercial wind turbines generated the parameters for theoretical models that served as guidelines for practical design work. Interactions between the DWTS and industry contributed to a steady improvement of wind turbine performance. These improvements added up: for example, between 1981 and 1984 the performance of $55 \mathrm{~kW}$ machines improved by more than $50 \%$.

\subsubsection{Contrasting processes in the US}

The co-involved relationship that the DWTS had with its industry participants was not to be found in the relationship between the NREL and wind turbine firms that were operating in the US. NREL was never able to develop the kind of extensive, on-going, trusting relationship with the commercial wind turbine industry that would have allowed industry participants to shape the laboratory's research agenda. In fact, distrust of the laboratory increased after one of its engineers who had tested some early commercial turbines left in 1980 to form his own turbine company, ESI (Karnøe, 1993).

NREL's genesis can be traced to US government's support of small-scale wind turbine R\&D in 1977. Originally known as the Solar Energy Research Institute, its name was later changed to the National Renewable Energy Laboratory, which more closely reflected its institutional roots, the government-directed US National Laboratories program (e.g. Los Alamos, Brookhaven, and Livermore). The first three researchers hired were academics, with backgrounds in aerodynamics and electrical engineering. The managers, meanwhile, came from the DOE. The center's organization and set of skills exemplified 


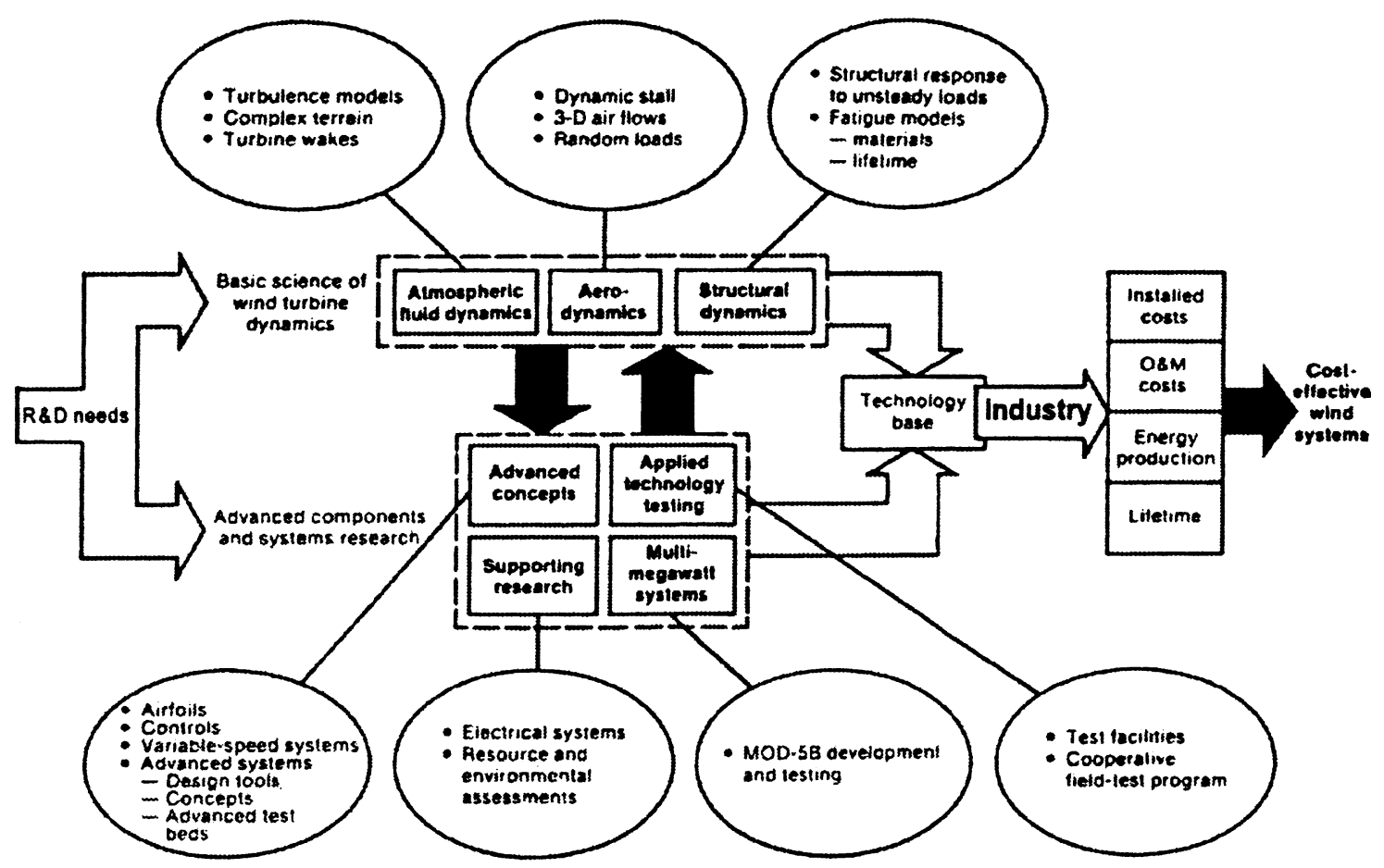

Notes: This figure is from from "DOE Five Year Researc h Plan on wind power, 1985-90." It depicts the technology push approa ch to the development of a hi gh-tech wind turbine that shaped the interaction of researchers at SERI/NERL.

Fig. 5. An illustration of a "linear model" directing involvement of US test center.

its government-derived mission, to pursue basic engineering science research in order to establish the theoretical basis for the design of an "ideal" wind turbine (see Fig. 5 for the linear mission oriented approach adopted by the SERI/NERL).

Given its institutional roots, it is no coincidence that both incarnations of the SERI/NREL had the word "research" in their titles but not the word "testing." Although testing was its first assignment, SERI/NREL shied away from the systematic testing of commercial turbines under simulated and actual conditions of use that would have identified and measured progress on practical industry problems. Instead, perceiving the pursuit of fundamental engineering science research as its primary mission, the SERI/NERL focused on inducing those in the industry to generate a revolutionary design. In 1993, commenting on the American wind turbine firms" ability to "leap-frog" the Danish firms, Robert Thresher, NREL's head exclaimed:

We are betting on it! With time, the light-weight, cost-effective turbine will win the race. (Davidson, 1993, p. 29)

By focusing efforts to find a high-tech turbine design based on fundamental scientific principles, the SERI/NERL activities generated abstract models that were too theoretical to provide the kind of systematic comparative testing and simulation feedback that the industry most needed. This focus on developing a high-tech design may have led to critical delays in NREL's inputs to the emerging path. It appears that those in industry were often ahead of the SERI/NERL as captured by this quotation from a book on wind turbines by Gipe, one of the pioneers in the US path: 
It took NREL two to three years to develop advanced wind turbine blades. This is about the same amount of time as the entire turbine development cycle in Denmark, where, through the 1980s and 1990s, a new model was introduced every two years. 'When we needed blades,' said Zond's Kevin Cousineau, 'we built our own' rather than wait for NREL. 'When NREL decided to build a strain gauge test,' continued Cousineau, 'we'd had ours in operation for several years. (Gipe, 1995, p. 92)

The weak linkage between the SERI/NERL and industry was especially noticeable in the lack of a systematic testing program for commercial turbines. There were tests conducted, but the first test reports were delayed by several years. Nor were the reports themselves very informative. Tests, when conducted at all, tended to be done using small older machines, with no follow-up using full-scale newer ones. For example, in 1992, the largest turbine at the test site was a small $20 \mathrm{~kW}, 12$-year-old machine (Summers, 1992).

Eventually, even Thresher, the engineering science oriented head of SERI/NERL came to the realization that laboratory's research activities were too theoretical and abstract to be of much practical use. After his visit to the Danish DWTS in 1992, Thresher commented:

I looked out a picture window and saw six turbines all in a row, and there was a $500-\mathrm{kW}$ machine right outside the window. Our research and testing activities at RockyFlats were becoming irrelevant because we were working at too small a scale. We're going to focus our research and testing on the same class and size machine that will be deployed in the field. We have to be relevant and it must be speedy. (Thresher quoted in Summers, 1992)

In his reflection, Thresher was finally acknowledging the key opportunities that the SERI/NERL had lost in gaining an appreciation of the parameters required to simulate designs by not establishing multiple points of contact with nature. In 1992, reflecting on outcomes of the differences in the approaches in Denmark and in the US, Stoddard, himself an author of an influential book on wind turbines (Eggleston and Stoddard, 1987), noted that the DWTS had contributed 12 of 25 most important papers on the design of wind turbines between 1977 and 1990 in contrast to the five that emerged from the US SERI/NERL.

\subsection{Regulatory involvement}

Regulatory actors play critical roles in the designing rules that govern the functioning of markets (Kemp et al., 1988, 2001). Well before new technologies become viable, these actors step in with subsidies and grants to nurture and shape an emerging technology. They also enact laws that govern the interactions of those involved in the development of a new technology. Regulatory policies in Denmark served the role of "steering" the Danish market from becoming too big too fast or withering away in times of trouble. In contrast, policies in the US first amplified and then abruptly terminated the wind gold rush, thereby generating considerable problems for US wind turbine firms.

\subsubsection{Processes in Denmark}

Lying dormant since the 1950s, wind turbine technology was neglected largely due to an earlier focus on oil and nuclear power. Galvanized by the energy crisis of 1974, a Wind Energy Committee by the Danish Academy of Technical Sciences concluded that wind power was economically viable and earmarked R\&D money, primarily for the development of large-scale wind turbines (Karnøe, 1991; Lauritsen et al., 1996). ${ }^{4}$ A development contract was also awarded to a newly formed consortia comprising utilities, the Technical University and major industrial firms. Despite these initiatives, no commercial technology emerged (Karnøe, 1991). In contrast, the modest 3-year grant to the test center (DWTS) established on an experimental basis emerged to play an important role in the development of modern wind power.

The second energy crisis of 1979 led to a substantial 30\% investment subsidy for buyers of certified wind turbines. The energy crisis and the Three Mile Island nuclear accident offered political actors the

\footnotetext{
${ }^{4}$ In the case of wind turbines, Gipe (1995, Table 3.1) estimates that total public R\&D spending between 1974 and 1992 in the US was around US\$ 486 million (on large and small scale wind turbines) compared to US\$53 million in Denmark and that the total market subsidies in the US was around US\$ 900 million as compared to US\$ 150 million in Denmark.
} 
much needed legitimacy for regulators to "interfere" with market forces (Karnøe, 1991, 1992). A new Energy Plan 1981, based on fossil fuels, nuclear power, and energy savings, projected possible installations of 10,000 wind turbines by 2000 . This plan gave credibility to the actors associated with the emerging industry.

Despite these subsidies, wind power installations in the Danish home market remained small. To stimulate the home market, subsidies were raised to $50 \%$. Besides, wind turbine owners were refunded a new fossil fuel energy tax for each kWh of electricity generated by wind power. Moreover, buckling under political pressure, the utilities agreed to pay owner-users for wind power at a rate of $70-85 \%$ of the prices they could command for power distributed through their grid. These initiatives resulted in enhancing turbine installations from $8 \mathrm{MW}$ in 1984 to $25 \mathrm{MW}$ in 1985. However, the special wind farm subsidy ended in 1986 as those living in areas with wind farms began complaining about the profits being made by wind turbine owners who did not have to live near installations.

Despite a major government shift from social democratic to neo-liberal in 1982, the new political coalition behind the Energy Plan 1981 prevailed. Several events occurred that legitimized regulatory interventions. These included high unemployment, Danish exports to California, the 1986 Chernobyl nuclear accident, and the 1987 Brundtland report on sustainability. In 1989, a new Energy Plan 2000 formally restated the ambitious goal of producing $10 \%$ of Danish electricity through wind power by year 2000 (Karnøe, 1992). However, a right-wing government stopped it, and it was not till a new government in 1995 formally articulated carbon dioxide as a major problem that this goal was politically stabilized.

Not all positive outcomes were a result of foresight. In December 1985, the minister of energy managed to persuade utilities to make investments in wind power. They agreed to install $100 \mathrm{MW}$ from 1986 to 1990 in return for a policy that restricted private investments in wind power. This regulation prevented a "Danish wind rush" that would have cluttered sites with small and relatively inefficient wind turbines when the California market collapsed.

In sum, building upon crisis, temporary victories and serendipitous events, a fragile yet persistent political coalition around wind energy was able to "steer" the Danish wind turbine path to its modern incarna- tion. Regulators were able to "modulate" the growth of the industry with policies flexible enough to rectify temporary undesirable outcomes. For instance, adapting to the increased efficiency of wind turbines, direct investment subsidies were reduced gradually from $30 \%$ in 1979 to $25 \%$ in $1983,20 \%$ in 1985 , $15 \%$ in 1987, 10\% in 1988 with no subsidy in 1989 .

\subsubsection{Contrasting processes in the US}

The oil embargo of 1974 galvanized the US government to search for alternative energy sources. Representing a transition from the National Science Foundation (NSF, 1973), the SERI was empowered to use NASA's expertise. Under this legislation, around US\$ 486 million was spent on wind power R\&D between 1974 and 1992 (Gipe, 1995). Seventy-five percent of this was set aside for contractors developing large size wind turbines and the remaining for those developing small-scale turbines (Karnøe, 1993; Gipe, 1995; Righter, 1996). Neither of these initiatives resulted in a viable wind turbine technology.

In contrast, policies to stimulate US markets had a greater impact on the emergence of modern wind turbines (Karnøe, 1993; Righter, 1996; Gipe, 1995, pp. 30-36). Among the more important policies was Jimmy Carter's National Energy Act of 1978. This policy encouraged energy conservation, a market for non-utility generators and a $15 \%$ tax credit to stimulate the development of renewable energy. A particularly important institutional innovation was the PURPA. PURPA required utilities to buy wind electricity at a price that reflected savings from reduced marginal production. However, it took strong political pressure to break the utility monopoly before PURPA had any effect (Righter, 1996).

In California, governor Jerry Brown built upon the momentum set by these federal initiatives to create the Office of Appropriate Technology (OAT) to promote energy self-sufficiency and soft renewable energy technologies (Righter, 1996, p. 196). Henry Mello's Act of 1978 targeted wind energy to cover $1 \%$ of California's electrical energy consumption by 1987 and $10 \%$ by 2000 . Among renewable energy sources, wind power gained most of the combined federal and California tax credits.

In combination, the tax credits and the PURPA buy back program created the California wind gold rush of the early 1980s. About 12,000 wind turbines were 
installed in California between 1981 and 1986. The $1100 \mathrm{MW}$ that was installed represented $95 \%$ of total wind power installations in the world. It is interesting to note that these incentive structures reduced possibilities of feedback that might have emerged from use informing those designing and producing wind turbines. As Pouslen, the Managing Director of Vestas pointed out:

In Denmark, it was an investment subsidy and guaranteed high power prices. In the U.S., a depreciation and tax credit was used. It encouraged limited partnerships. Most American investors never saw a wind turbine. They were doctors and dentists, and once they got their tax credits, they were satisfied. By contrast, the Danish system required investors to generate electricity. (Business Week Online, 06/11/2001)

The California wind energy gold rush came to an abrupt end when the Reagan administration did not extend tax credits beyond 1985. The weakened business climate dramatically reduced the momentum of the emerging path as developers and producers, experiencing financial difficulties, began declaring bankruptcy. Moreover, many installed wind turbines began confronting technical problems. Developers could not fulfill production schedules and producers had problems financing guaranteed repairs. A long chain of law suits were initiated as "cities sued federal agencies, investors sued wind farm companies, wind farm companies sued manufacturers, and manufacturers sued insurance companies." (Righter, 1996, p. 216).

In retrospect, there appears to have existed a misconceived belief in the 1980s that wind power technology was sufficiently developed for large-scale economic use (van Est, 1999). This misconception resulted in the enactment of policies that fueled and then abruptly stopped growth. This process was not conducive to the smooth development of a technology path. The "on-off" policy did not provide the space and time for the technology and engineering skills to mature in a systematic fashion.

\section{Bricolage versus breakthrough}

We began this paper by highlighting the distributed nature of human agency associated with technology entrepreneurship. As our description illustrates, technology entrepreneurship entails not just the discovery of opportunities by alert individuals or speculation on the future but also the creation of new opportunities by a collective. In the emergence of wind turbines, the creative synthesis that occurred as users and producers interacted with one another is apparent in the design of the double brake system. It is also apparent in the design of flexible fiber-glass wind turbine blades that emerged from the intersection of the knowledge bases of the two Carters. Yet, however visible these outcomes of synthesis might appear, the process of emergence entailed a continual accretion of inputs that progressively shaped the emerging paths.

In our framing of technology entrepreneurship as being distributed, we had sought an understanding of the processes that could harness the inputs of distributed actors. In this regard, we had suggested that actors become embedded in accumulating artifacts, tools, practices, rules and knowledge. Our accounts illustrate such embedding processes. In both settings, a steady accretion of inputs generated a momentum that offered participants a way to "entrain" themselves into the emerging technological path, making it possible for them to interact with one another.

It is possible for different paths to emerge depending upon specific starting positions and subsequent dynamics that unfold. As our comparative descriptions illustrate, actors in the US pursued an approach that attempted to generate a breakthrough. In contrast, those in Denmark pursued an approach that we label as bricolage. These overall differences in orientations were manifest in how producers, users, evaluators and regulators became involved with each of the paths.

For instance, producers in the US attempted to design a high-tech, light-weight, high-speed turbine. In contrast, producers in Denmark progressively scaled up from a heavy-weight low-speed simplistic design. An alignment of ownership and usage generated incentives for owner-users in Denmark to be vigilant. In contrast, a separation of ownership from usage dampened and delayed critical feedback in the US. In Denmark, the test station emerged as a forum for mutual knowledge building and sharing between various actors. In contrast, the research institute in the US served as an "exogenous" selection mechanism. Regulatory actors in Denmark were able to "modulate" conditions with policies "aimed at keeping the process 
of change going in desirable directions" (Kemp et al., 1988, p. 185). In contrast, the hands-off style of regulatory actors in the US led to policies that were not conducive to the continual development of wind turbine technology.

These comparisons highlight differences in the patterns of actor involvement between the two paths. Actors in Denmark appear to have had a more "hands-on" quality to their interactions, not only with the technology-in-the-making, but also with one another. Their actions and interactions were marked by continual adjustment required for bricolage to occur (Dorf and Sabel, 1998). In contrast, formal theoretical models, more typical of a breakthrough approach, appear to have mediated actions and interactions between actors and artifacts in the US setting. Because of the higher distance that such mediated interactions created, the involvement of actors with the artifacts and with one another had more of a "hands-off" quality than what was to be found in Denmark.

These observations offer a deeper understanding of bricolage and breakthrough processes that go beyond differences in the ways in which individual actors became involved. Specifically, they highlight how inputs of the actors either reinforced or stalled emerging paths. In the Danish case, for instance, the coupling of different learning processes stimulated wind turbine improvements (Rosenbloom and Cusumano, 1987). Learning from multiple installation sites, in combination with learning on the shop floor, became the bases for design scale-ups. Shaping this process were results of comparative tests conducted by the DWTS that became the bases for a steady accumulation of valuable knowledge across wind turbine firms. Indeed, those crafting regulatory policies did so by enrolling the many actors involved, including utilities, wind mill owner-users and producers to develop an energy policy that kept the network in motion as actors co-shaped the emerging path. There were no grand plans shaping the emergence of the path. Rather, distributed actors offered inputs to generate a virtuous learning circle to forge a viable technological path (see also Stacey, 1993).

The confluence of these learning processes associated with the Danish path resulted in co-shaping of the actors and artifacts constituting the emerging technological path. Indeed, the continual melding of inputs from actors in different domains resulted in the blurring of boundaries between design and production, planning and execution, rule making and rule following (see also Mintzberg et al., 1976; Bastien and Hostager, 1992; Weick, 1998; Hatch, 1997; Baker et al., 2000; Miner et al., 2001). There was less emphasis on developing dramatic outcomes. Instead, actors in Denmark gradually built up competencies (Karnøe, 1996). There was no overly rational, pre-planned approach driving the process (March, 1994, 1999). Instead, the path was emergent with actors improvising and adapting to unfolding structures as they gradually transformed the emerging path to higher functionalities (see also Burgelman, 1983; Mintzberg et al., 1976; Brown and Eisenhardt, 1997). Overall, the Danish technological path emerged in a way that was not entirely preordained and yet built upon the inputs of the many actors involved.

In the US, there was a lower degree of mutual co-shaping that was characteristic of bricolage in the Danish setting. For instance, design engineers and those on the shop floor did not provide each other with critical feedback, early users offered little feedback to shape the technology, designers' needs did not shape the research agenda of the SERI/NERL, and the quality of interactions between producers and researchers was poor. Although these actors depended upon one another to generate a momentum for the emerging path, they did not interact in ways that would allow for mutual co-shaping. Indeed, the lack of interaction between actors may have enhanced interpretive barriers between distributed actors, thereby reducing chances of success (Dougherty, 1992). Moreover, there appears to have been an "episodic" quality to the involvement of actors with the emerging path, an involvement driven by an overall desire to seek dramatic outcomes. Eventually, these processes were not conducive to the cumulative build up of a stock of knowledge on wind turbines to ensure their robust operations.

Florida and Kenney (1990, pp. 3-4) noted that "the legacy of America's ability to develop and, more importantly, commercialize breakthroughs is indeed impressive in the areas of mass-produced automobiles, radio, and television, and more recently in high technology." Yet, hinting at weaknesses associated with a breakthrough approach, Florida and Kenney highlight how foreign corporations caught up and, in some cases, overtook the US in high-technology 
sectors in the 1980s. In this regard, our study offers additional insights on the potential weaknesses of a breakthrough approach. We already know that attempts at coming up with breakthroughs risks alienating those with vested interests (Garud and Karnøe, 2001). Our study suggests that efforts to accomplish dramatic outcomes can result in dampening the learning processes required for mutual co-shaping to occur. Moreover, if a breakthrough approach fails, it becomes difficult for firms to chart a recovery. Systematic knowledge required to correct deficiencies may not be available. Moreover, problems with one set of actors can begin impacting others in a domino fashion (Venkataraman and Van de Ven, 1998). Resources, whether they are financial, intellectual or symbolic, can diminish rather rapidly in a negative spiral.

This was the situation with the wind turbine path in the US. Eventually, wind turbines designed in the US began failing in large numbers. The lack of a systematic base of knowledge whereby a remedial course could be charted handicapped a recovery. Fresh resources were not readily available. There was one new initiative-The Advanced Wind Power Programlaunched "to design and build the 'best' wind turbine as well as to assist industry by supplying advanced components" (Hock et al., 1991). Reproducing its earlier recipe toward designing the "best" design, this program too did not deliver. In this way, a vicious circle (Masuch, 1985) unfolded as turbines designed in the US continued to fail causing irreversible damage to the emerging technological path.

\section{Conclusion}

We have offered a perspective on technology entrepreneurship that highlights the distributed nature of agency. Actors from the domains of production, use, evaluation and regulation become involved in the development of a technology as was the case in the development of wind turbines. The development of technologies entails not just an act of discovery by alert individuals or speculation on the future, but also the creation of a new path through the distributed efforts of many. As with the emergence of wind turbines, path creation results in a steady accumulation of artifacts, tools, practices, rules and knowledge that begin shaping actors in the domains of design, production, use, evaluation and regulation. These accumulating inputs become the fabric within which and with which actors interact with the artifact and with one another to forge a new technological path. That is, agency is not only distributed but is embedded as well.

A key motivation for undertaking this study was to understand how a bricolage approach that begins with a low-tech design but ramps up progressively is able to prevail over a high-tech breakthrough approach. Underlying this puzzle was a premise that sophisticated high-tech breakthrough approaches confer advantages over seemingly simpler bricolage approaches. Our comparative study suggests that a high-tech breakthrough approach may possess inherent disadvantages. Specifically, an approach that attempts to generate a breakthrough can end up stifling micro-learning processes that allow for the mutual co-shaping of emerging technological paths to occur. That is, actors in the US may have failed, not despite, but because of their pursuit of a breakthrough.

Bricolage preserves emergent properties. It is a process of moving ahead on the basis of inputs of actors who possess local knowledge, but through their interactions, are able to gradually transform emerging paths to higher degrees of functionality (see also Gavetti and Levinthal, 2000; Lindblom, 1959; Quinn, 1978; Garud and Karnøe, 2001). Co-shaping occurs at several interaction points, between designers and shop floor workers, between producers and users, between external researchers and producers, and between policy makers and the markets that they regulate.

Such processes may be particularly valuable in situations characterized by complex non-linear dynamics among the actors, artifacts and rules that constitute a technological path. This was certainly the case with wind turbines. Additionally, they may be valuable in fast moving emerging environments where competencies, preferences, evaluation routines and institutional rules are co-emerging. For such processes to unfold, it is important to have a diversity of linkages to foster mutual involvement of actors (see also Florida and Kenney, 1990; Saxenian, 1996). Technological initiatives that do not build upon the inputs of relevant actors may neither mobilize the required skills and resources nor ensure its acceptance in the wider community. 


\section{Acknowledgements}

This is a fully collaborative project. The research was made possible by a grant from the Center for Interdisciplinary Studies in Technology Management (CISTEMA), Denmark. The paper has benefited from feedback offered by those attending Field Studies on Organizational Complexity, INFORMS, Atlanta, 1996, SCANCOR Conference on Samples of the Future, Stanford, 1998 and Conference on Knowledge and Innovation, Helsinki, 2000. We are indebted to Andres Garcia for his considerable help with earlier drafts of this paper. We thank Daniel Beunza, Roger Dunbar, Michelle Gittelman, Sanjay Jain, Kristian Kreiner, Arun Kumaraswamy and Dara Szyliowicz for their helpful comments. We thank Scott Shane, S. Venkataraman and anonymous reviewers for Research Policy whose key inputs have shaped this paper. We thank many people from the Danish and American wind turbine paths, especially B.T. Madsen, Peter Hjuler Jensen, Flemming Rasmussen, F.S. Stoddard, Paul Gipe and Per Dannemand Andersen.

\section{References}

Aldrich, H.E., 1999. Organizations Evolving. Sage Publications Ltd., Thousand Oaks, CA.

Aldrich, H.E., Fiol, C.M., 1994. Fools rush in? The institutional context of industry creation. Academy of Management Review 19, 645-670.

Andersen, P.D., 1993. An Analysis of Technological Innovation in the Danish Wind Turbine Industry: The Role of the Test and Research Center. Unpublished doctoral dissertation IOA, Copenhagen Business School, Copenhagen, Denmark.

Argote, L., Epple, D., 1990. Learning curves in manufacturing. Science 247, 920-924.

Arrow, K., 1962. The economic implications of learning by doing. Review of Economic Studies 29 (June), 155-173.

Arthur, W.B., 1988. Self-reinforcing mechanisms in economics. In: Anderson, P., et al. (Eds.), The Economy as an Evolving Complex System. Addison-Wesley, Reading, MA.

Arthur, W.B., 1989. Competing technologies, increasing returns, and lock-in by historical events. The Economic Journal 99, 116-131.

Baker, T., Miner, A., Easley, D., 2000. Improvising Firms: Bricolage, Retrospective Interpretation and Improvisational Competencies in the Founding Process. In: Proceedings of the Technology Entrepreneurship Research Policy Conference, University of Maryland, Maryland.

Bastien, D., Hostager, T., 1992. Cooperation as communicative accomplishment. A symbolic interaction analysis of an improvised jazz concert. Communication Studies 43, 92-104.
Baumol, W.J., 1990. Entrepreneurship: productive, unproductive and destructive. Journal of Political Economy 98 (5), 893-921.

Bijker, W.E., 1987. The social construction of bakelite: toward a theory of invention. In: Bijker, W.E., Hughes, T.P., Pinch, T.J. (Eds.), The Social Construction of Technological Systems: New Directions in the Sociology and History of Technology. MIT Press, Cambridge.

Bijker, W.E., Law, J., 1992. Shaping Technology/Building Society: Studies in Sociotechnical Change. MIT Press, Cambridge, MA.

Bijker, W.E., Hughes, T.P., Pinch, T.J., 1987. The Social Construction of Technological Systems: New Directions in the Sociology and History of Technology. MIT Press, Cambridge, MA.

Braun, E., Macdonald, S., 1982. Revolution in Miniature: The History and Impact of Semiconductor Electronics Re-explored. Cambridge University Press, New York.

Brown, S.L., Eisenhardt, K.M., 1997. The art of continuous change: linking complexity theory and time-paced evolution in relentlessly shifting organizations. Administrative Science Quarterly 42 (1), 1-34.

BTM Consult, 2001. International Wind Energy Development, World Market Up-date 2000.

Burgelman, R.A., 1983. A process model of internal corporate venturing in the diversified major firm. Administrative Science Quarterly 28, 223-244.

Callon, M., 1991. Techno-Economic networks and irreversibility. In: Law, J. (Ed.), A Sociology of Monsters: Essays on Power, Technology and Domination. Routledge, London.

Callon, M., 1998. Introduction-the embeddedness of economic markets in economics. In: Callon, M. (Ed.), The Laws of the Markets. Blackwell Publishers, Oxford, UK.

Casson, M., 1995. Entrepreneurship and Business Culture: Studies in the Economics of Trust. Edward Elgar, Brookfield.

Choi, Y.B., 1993. Paradigms and Conventions: Uncertainty, Decision Making and Entrepreneurship. The University of Michigan Press, Ann Arbor.

Constant, E., 1980. The Origins of the Turbojet Revolution. The Johns Hopkins University Press, Baltimore, MD.

David, P.A., 1985. Clio and the economics of QWERTY. American Economic Review 75, 332-337.

Davidson, R., 1993. In Search of Wisdom, Windpower Monthly, July, pp. 25-29.

Davidson, R., 1996a. A New Start, Windpower Monthly, 4 June, p. 4.

Davidson, R., 1996b. Kenetech Files for Bankruptcy Protection, Windpower Monthly, 4 June, pp. 20-21.

Divone, L.V., 1980. The Current Perspective on Wind Power Based on Recent US Results. In: Proceedings of the Third International Symposium on Wind Energy Systems, The Technical University of Denmark. BHRA Fluid Engineering, Cranfield, UK.

Dobbin, F., 1994. Forging Industrial Policy, Cambridge University Press, New York.

DOE, 1984. Five Year Research Plan 1985-90-Wind Energy Technology: Generating Power from the Wind. DOE/CE-T11. UC Category 60. Department of Energy, United States.

Dorf, M.C., Sabel, C.F., 1998. A constitution of democratic experimentalism. Columbia Law Review 98 (2), 267-473.

Dosi, G., 1982. Technological paradigms and technological trajectories. Research Policy 11, 147-162. 
Dougherty, D., 1992. Interpretive barriers to successful product innovation in large firms. Organization Science 3, 179-202.

Dowd, T., Dobbin, F., 1997. The Embedded Actor and the Invention of Natural Law, American Behavioral Scientist, vol. 40 (4), February. Sage, Beverley Hills, CA.

Dutton, J.M., Thomas, A., 1985. Relating technological change and learning by doing. In: Richard, D.R. (Ed.), Research on Technological Innovation, Management, and Policy, vol. 2. JAI Press, Greenwich, CT, pp. 187-224.

Eggleston, D.M., Stoddard, F.S., 1987. Wind Turbine Engineering Design. Van Nostrand Reinhold, New York.

Florida, R., Kenney, M., 1990. The Breakthrough Illusion: Corporate America's Failure to Move from Innovation to Mass Production. Basic Books, New York.

Garrad, A., 1988. Future Needs Close Cooperation Between Mathematicians and Manufacturers. WindPower Monthly, April, pp. 23-25.

Gartner, W.B., 1988. "Who is an entrepreneur" is the wrong question. American Journal of Small Business 12 (4), 11-32.

Garud, R., 1997. On the distinction between know-how, know-why and know-what in technological systems. In: Walsh, J., Huff, A. (Eds.), Advances in Strategic Management. JAI Press, Greenwich, CT, pp. 81-101.

Garud, R., Jain, S., 1996. The embeddedness of technological systems. Advances in Strategic Management 13, 389-408.

Garud, R., Karnøe, P., 2001. Path creation as a process of mindful deviation. In: Garud, R., Karnøe, P. (Eds.), Path Dependence and Creation. Lawrence Earlbaum Associates, Mahwah, NJ, pp. $1-38$.

Garud, R., Kotha, S., 1994. Using the brain as a metaphor to model flexible productive units. Academy of Management Review 19 (4), 671-698.

Garud, R., Rappa, M., 1994. A socio-cognitive model of technology evolution. Organization Science 5 (3), 344-362.

Garud, R., Van de Ven, A.H., 1987. Innovation and the emergence of industries. In: Proceedings of the Academy of Management National Meeting, New Orleans, pp. 319-322 (Best Paper).

Garud, R., Kumaraswamy, A., Nayyar, P., 1998. Real options or fool's gold: perspective makes the difference. Academy of Management Review, Discussion Forum 3 (2), 212-214.

Garud, R., Jain, S., Kumaraswamy, A., 2002. Orchestrating institutional processes for technology sponsorship: the case of Sun Microsystems and Java. Academy of Management Journal 45, 196-214.

Gavetti, G., Levinthal, D., 2000. Looking forward and looking backward: cognitive and experiential search. Administrative Science Quarterly 45, 113-137.

Giddens, A., 1979. Central Problems in Social Theory: Action, Structure and Contradiction in Social Analysis. University of California Press, Los Angeles.

Gipe, P., 1995. Wind Energy Comes of Age. Wiley, New York.

Girard, M., Stark, D., 2001. Distributed Intelligence and the Organization of Diversity in New Media Projects. In: Proceedings of the Workshop "Beyond the Firm?", University of Bonn.

Golding, E.W., 1955. The Generation of Electricity by Wind Power. E\&FN Spon., London (Reprinted by Wiley, 1976).
Harper, D., 1996. Entrepreneurship and the Market Process. Routlidge, London.

Hatch, M.J., 1997. Jazzing up the theory of organizational improvisation. In: Walsh, J., Huff, A. (Eds.), Advances in Strategic Management. JAI Press, Greenwich, CT, pp. 181-191.

Hayek, F.A., 1945. The use of knowledge in society. The American Economic Review XXXV (4), 519-532.

Hock, S., Thresher, R.W., Goldman, P.R., 1991. The Federal Advanced Wind Turbine Program. In: Proceedings of the Windpower ' 91 Conference and Exposition, Palm Springs, CA, 24-27 September 1991. National Renewable Energy Laboratory, Golden, CO.

Hughes, T.P., 1983. Networks of Power. The John Hopkins University Press, Baltimore, MD.

Hughes, T.P., 1989. American Genesis: A Century of Invention and Technological Enthusiasm 1870-1970. Viking Penguin, New York.

Jain, S., 2001. A Process Framework of Collective Standards Emergence. Unpublished doctoral dissertation, New York University, New York.

Jørgensen, U., Karnøe, P., 1995. The Danish wind turbine story: technical solutions to political visions? In: Rip, A., Misa, T.J., Schot, J. (Eds.), Managing Technology in Society: The Approach of Constructive Technology Assessment. Pinter Publishers, London.

Karnøe, P., 1991. Danish Wind Turbine Industry-A Surprising International Success: On Innovations, Industrial Development and Technology Policy (in Danish). Samfundslitteratur, Copenhagen.

Karnøe, P., 1992. En kamp for vindmøller: Den Sociale Konstruktion af en konstruktiv Teknologi. In: Torben, A.I. (Ed.), Konstruktiv Teknologi. Nyt fra Samfundsvidenskaberne.

Karnøe, P., 1993. Approaches to Innovation in Modern Wind Energy Technology: Technology Policies, Science, Engineers and Craft Traditions. Center for Economic Policy Research Publication \# 334, Stanford, CA.

Karnøe, P., 1996. The social process of competence building. International Journal of Technology Management 11 (7/8), 770-789.

Karnøe, P., 2001. Markets-in-the-Making: The Co-Evolution of Commodities and Transactional Spaces IOA. Copenhagen Business School Working Paper.

Karnøe, P., Garud, R., 2001. Path creation and dependence in the Danish wind turbine field. Copenhagen Business School Working Paper.

Karnøe, P., Kristensen, P.H., Andersen, P.H., 1999. Mobilizing Resources and Generating Competencies: The Remarkable Success of Small and Medium Sized Enterprises in the Danish Business System. Copenhagen Business School Press, Copenhagen, Denmark.

Kemp, R., Schot, J., Hoogma, R., 1988. Regime shifts to sustainability through processes of niche formation: the approach of strategic niche management. Technology Analysis and Strategic Management 10 (2), 175-195.

Kemp, R., Rip, A., Schot, J., 2001. Constructing transition paths through the management of niches. In: Garud, R., Karnøe, P. (Eds.), Path Dependence and Creation. Lawrence Earlbaum Associates, Mahwah, NJ, pp. 269-302. 
Kirzner, I.M., 1997. Entrepreneurial discovery and the competitive market process: an Austrian approach. Journal of Economic Literature 35 (March), 60-85.

Kline, R.K., Pinch, T.J., 1996. Users as agents of technological change: the social construction of automobile in the rural United States. Technology and Culture 37, 763-779.

Knight, F.H., 1971. Risk, Uncertainty and Profit. University of Chicago Press, Chicago.

Kreiner, K., Tryggestad, K., 2002. The co-production of chips and society. Scandinavian Journal of Management 18, 421-449.

Kristensen, P.H., 1992. Strategies against structure: institutions and economic organization in Denmark. In: Whitley, R. (Ed.), European Business Systems: Firms, Markets and their National Contexts. Sage, San Francisco.

Latour, B., 1991. Technology is society made durable. In: Law, J. (Ed.), A Sociology of Monsters-Essays on Power, Technology and Domination. Routledge, London.

Lauritsen, A.S., Svendsen, T., Sørensen, B., 1996. Wind power in Denmark. Final Report of APAS/RENA project for European Union, Denmark.

Layton, E., 1971. Mirror-image twins: The Community of Science and Technology in 19th-century America. Technology and Culture 12, 562-580.

Levi-Strauss, C., 1967. The Savage Mind. University of Chicago Press, Chicago.

Lindblom, C.E., 1959. The science of 'muddling through'. Public Administration Review 19, 79-88.

Lundsager, P., Jensen, P.H., 1982. Licensing of Windmills in Denmark. In: Proceedings of the Fourth International Symposium on Wind Energy Systems, Stockholm, 21-24 September 1982.

Lundval, B. (Ed.), 1992. National Systems of Innovation: Towards a Theory of Innovation and Interactive Learning. Pinter Publishers, London.

March, J.G., 1994. A Primer on Decision Making. Free Press, New York.

March, J.G., 1999. The Pursuit of Organizational Intelligence. Blackwell, Malden, MA.

Masuch, M., 1985. Vicious circles in organizations. Administrative Science Quarterly 30, 14-33.

Mezias, S.J., Kuperman, J.C., 2000. The community dynamics of entrepreneurship: the birth of the American film industry, 1895-1929. Journal of Business Venturing 16, 209-233.

Miner, A.S., Bassoff, P., Moorman, C., 2001. Organizational improvization and learning: a field study. Administrative Science Quarterly 46, 304-337.

Mintzberg, H., Raisinghani, O., Theoret, A., 1976. The structure of unstructured decision processes. Administrative Science Quarterly 21, 246-275.

Mises, L., 1978. Planning for Freedom. Libertarian Press, South Holland, IL, 1980.

Molina, A., 1999. Understanding the role of the technical in the build-up of sociotechnical constituencies. Technovation 19, $1-29$.

Nelson, V., 1983. State of the SWECS Industry in The United States. Unpublished paper, Alternative Energy Institute, West Texas State University.
Nelson, R.R., 1994. The coevolution of technologies and institutions. In: England, R.W. (Ed.), Evolutionary Conceptions in Contemporary Economics. The University of Michigan Press, Ann Arbor.

Nelson, R.R., Winter, S.G., 1982. An Evolutionary Theory of Economic Change. The Belknap Press of Harvard University Press, Cambridge, MA.

Noble, D., 1984. Forces of Production: A Social History of Industrial Automation. Knopf, New York.

NSF/NASA, 1973. In: Proceedings of the Workshop on Wind Energy Conversion Systems, 11-13 June 1973, Washington, DC. NSF/RA/W-73-006, December.

Pinch, T.J., 2001. Why do you go to a piano store to buy a synthesizer: path dependence and the social construction of technology. In: Garud, R., Karnøe, P. (Eds.), Path Dependence and Creation. Lawrence Earlbaum Associates, pp. 381-399.

Pinch, T.J., Bijker, W.E., 1987. The social construction of facts and artifacts: or how the sociology of science and the sociology of technology might benefit each other. In: Bijker, W.E., Hughes, T.P., Pinch, T.J. (Eds.), The Social Construction of Technological Systems: New Directions in the Sociology and History of Technology. MIT Press, Cambridge.

Porac, J., Rosa, J., Spanjol, J., Saxon, M., 2001. America's family vehicle: path creation in the US minivan market. In: Garud, R., Karnøe, P. (Eds.), Path Dependence and Creation. Lawrence Earlbaum Associates, Mahwah, NJ, pp. 213-242.

Porter, M.E., 1990. The Competitive Advantage of Nations. The Free Press, New York.

Putnam, P.C., 1948. Power From the Wind, Van Nostrand Reinhold, New York.

Quinn, J.B., 1978. Strategic change: logical incrementalism. Sloan Management Review 20 (1), 7-21.

Rao, H., 1998. Caveat emptor: the construction of nonprofit consumer watchdog organizations. American Journal of Sociology 103 (4), 912-961.

Righter, R.W., 1996. Wind Energy in America: A History. Oklahoma University Press, Norman.

Ris $\varnothing$, 1988. Prøvestationen for Vindmøller 1978-1988. Forskningscenter Ris $\varnothing$, Denmark. ISBN: 87-550-1475-5.

Rosenberg, N., 1982. Inside the Black Box: Technology and Economics. Cambridge University Press, New York.

Rosenbloom, R.S., Cusumano, M.A., 1987. Technological pioneering and competitive advantage: the birth of the VCR industry. California Management Review 29 (4), 3-22.

Rosenkopf, L., Tushman, M., 1993. The co-evolution of technology and organization. In: Baum, J., Singh, J. (Eds.), Evolutionary Dynamics of Organizations. Oxford University Press, New York.

Saxenian, A., 1996. Regional Advantage: Culture and Competition in Silicon Valley and Route 128. Harvard University Press, Cambridge, MA.

Schumpeter, J., 1942. Capitalism, Socialism and Democracy. Harper and Brothers, New York.

Shane, S., 2000. Prior knowledge and the discovery of entrepreneurial opportunities. Organization Science 11 (4), 448-469. 
Shane, S., Venkataraman, S., 2000. The promise of entrepreneurship as a field of research. Academy of Management Review 25 (1), 217-226.

Shepard, D.G., 1990. Historical Development of the Windmill, NASA Contractor Report 4337, DOE/NASA-5266-2, NASA, Office Management, Scientific and Technical Information Division.

Stacey, R.D., 1993. Strategic Management and Organizational Dynamics. Pitman Publishing, London, UK.

Stoddard, F.S., 1986. The California Experience. In: Proceedings of the Danish Wind Energy Association Wind Energy Conference, Herning, Denmark.

Stoddard, F.S., 1993. Detailed comments on the development of wind turbines in a letter to Peter Karnøe, 5 January.

Summers, P., 1992. Wind energy research takes flight: DOE unveils plans for the nation's most advanced user facility for wind energy research. In: NREL in Review: Science and Technology. National Renewable Energy Laboratory, November 1992.

Teece, D.J., 1987. Profiting from technological innovation: implications for integration, collaboration, licensing and public policy. In: Teece, D.J. (Ed.), The Competitive Challenge: Strategies for Industrial Innovation and Renewal. Ballinger, Cambridge, MA, pp. 185-219.

Tranæs, F., 2000. Danish Wind Energy Co-operatives. Part 1. Available on http://www.windpower.dk/articles/coop.html.

Tripsas, M., 2001. Understanding the timing of technological transitions: the role of user preference discontinuities. In: Proceedings of the Academy of Management Meetings, Washington, DC.

Tsoukas, H., 1996. The firm as a distributed knowledge system: a constructionist approach. Strategic Management Journal 11-25, $11-25$.

Tushman, M.L., Anderson, P., 1986. Technological discontinuities and organizational environments. Administrative Science Quarterly 31, 439-465.
Usher, A.P., 1954. A History of Mechanical Inventions. Harvard University Press, Cambridge.

Utterback, J.M., Abernathy, W.J., 1975. A dynamic model of process and product innovations. OMEGA 3, 639-656.

Van de Ven, A.H., 1993. A community perspective on the emergence of innovations. Journal of Engineering and Technology Management 10, 23-51.

Van de Ven, A.H., Garud, R., 1993. The co-evolution of technical and institutional events in the development of an innovation. In: Baum, J., Singh, J. (Eds.), Evolutionary Dynamics of Organizations. Oxford University Press, New York, pp. 425-443.

Van de Ven, A.H., Polley, D., Garud, R., Venkataraman, S., 1999. The Innovation Journey. Oxford University Press, New York.

van Est, R., 1999. Winds of Change: A Comparative Study of the Politics of Wind Energy Innovation in California and Denmark. International Books, Amsterdam.

Van Looy, B., Debackere, K., Bouwen, R., 2001. Innovation as community spanning process: looking for interaction strategies to handle path dependency. In: Garud, R., Karnøe, P. (Eds.), Path Dependence and Creation. Lawrence Earlbaum Associates, Mahwah, NJ, pp. 329-354.

Venkataraman, S., 1997. The distinctive domain of entrepreneurship research. In: Katz, J. (Ed.), Advances in Entrepreneurship: Firm Emergence and Growth. JAI Press, Greenwich, CT.

Venkataraman, S., Van de Ven, A.H., 1998. Environmental jolts, transaction sets and new business development. Journal of Business Venturing 13 (3), 23-255.

Von Hippel, E., 1986. Lead users: a source of novel product concepts. Management Science 32, 791-805.

Weick, K.E., 1979. The Social Psychology of Organizing. Random House, New York.

Weick, K.E., 1998. Improvisation as a mindset for organizational analysis. Organization Science 9, 543-555. 